POLISH POLITICAL SCIENCE

VOL XXXVII 2008

PL ISSN 0208-7375

\title{
COHABITATION: THE PARLIAMENTARY ASPECT OF THE FRENCH SEMI-PRESIDENTIAL SYSTEM
}

\author{
by Małgorzata Madej
}

The political system of the French Fifth Republic is referred to as "semi-presidentialism". This is to indicate its mixed nature - of a system presidential and parliamentary at a time. The Constitution grants broad prerogatives - and assigns serious tasks to both the head of state - le Président de la République - and the chief of government - le Premier ministre. When the prime minister represented the pro-presidential political camp, the head of state gained very serious influence on governing the state and political strategy (first, when the French political scene was dominated by the right - 1958-1981; then by the left - 1981-1986 and 1988-1993; and finally by the right again 1995-1997 and since 2002). As early as during Charles de Gaulle presidency (1958-1969) the idea called domaine reservée came into existence. According to this political concept, the widelyinterpreted external policies - including foreign affairs and defence were recognised as presidential prerogatives, regardless the of literal construction of legal provisions.

Relations within the executive changed radically with the end of political unity. During the so-called cohabitation French political practices were different and they ultimately led to an amendment of the Constitution.

\section{QUASI-COHABITATION 1974-1976 \\ (GISCARD D'ESTAING-CHIRAC PERIOD)}

For the first time posts of the President of the Fifth Republic and his Prime Minister were taken by representatives of different parties in 1974. This year the liberal 
politician Valéry Giscard d'Estaing was elected president and he appointed a rightist Gaullist Jacques Chirac chief of the government. He did so to reward Chirac's support during the electoral campaign, which had been decisive for d'Estaing's election - and the Gaullist Jacques Chaban-Delmas's defeat ${ }^{1}$. Due to this fact, Jacques Chirac the Prime Minister had a much stronger position than other chiefs of government of the Fifth Republic before him. Some researchers and politicians, including the then opposition leader, socialist François Mitterand, predicted an end to the presidential tradition and takeover of initiative by the Prime Minister.

Things went otherwise. Neither the head of state, nor the chief of government had freedom of move. However, d'Estaing was determined enough to cause Chirac to resign of his post after two years. The reason Chirac gave was "lack of means to perform his tasks"2. Giscard d'Estaing consistently implemented his own program of broad social liberalization: he lowered the age qualification for voting right, he increased the role of parliament and he decentralized public television. These changes gained support from the Socialist Party and could be introduced even against the Gaullists. ${ }^{3}$ However, Chirac's government did manage to block an important initiative by Giscard. The President did not take up the problem of the European Monetary Union, fearing the reaction of anti-integration Gaullist groups. This project was put on the agenda after the government was altered, by a new Prime Minister, Giscard's political ally Raymond Barre.

The two-year period of co-existence of the liberal President and Gaullist Prime Minister can't be treated as an example of classical cohabitation, because the parties of those two politicians made a coalition then, but the situation is worth noting in this context, as it demonstrates some regularities. Above all, obviously, the chief of government was stronger than before, both politically (being the leader of the biggest parliamentary fraction), and factually (being able to block presidential initiatives). It was also proved that it is impossible for two politicians to be in control simultaneously: president - "the guarantor of national independence, territorial integrity and observance of treaties" (art. 5 of the French constitution) and Prime Minister, who "determines and conducts the policy of the Nation" (art. 20 of the French Constitution). ${ }^{4}$ In 1976 it was the Prime Minister, who backed off, but the situation was different during actual cohabitations.

\footnotetext{
1 J. Baszkiewicz, Francja, Warszawa 1997, pp. 163-165.

2 Ibidem.

3 P. Bezbakh, Histoire de la France contemporaine de 1914 à nos jours, Paris 1990, p. 215.

4 http://www.assemblee-nationale.fr/english/8ab.asp
} 


\section{FIRST COHABITATION 1986-1988 (MITTERAND-CHIRAC PERIOD)}

In 1981 the socialist François Mitterand was elected the President of the Republic and he dissolved the National Assembly, chosen in 1978. In the early election his party took more than a half of the seats. However the policy of budgetary discipline, introduced after 1983 and resignation of the promises made during the electoral campaign led to disappointment of the leftist electorate and this trend was not changed even after the nomination of the radical leftist Laurent Fabius as Prime Minister. When the National Assembly's term finished in 1986, the new elections brought success to the rightist parties: the Gaullist Rassemblement pour la République and the liberal Union pour la démocratie française. Although they did not have a significant majority, it was enough to create a stable government (Tab. 1 and Fig. 1).

Tab. 1. First cohabitation, Mitterand-Chirac period, 1986-1988, composition of the 8th Assemblée Nationale:

\begin{tabular}{|l|c|c|}
\hline \multicolumn{1}{|c|}{ Party } & $\begin{array}{c}\text { number of } \\
\text { deputies }\end{array}$ & $\begin{array}{c}\text { percent of } \\
\text { deputies }\end{array}$ \\
\hline Parti Communiste Française (PCF) & 35 & 6.1 \\
\hline Parti Socialiste (PS) & 212 & 36.7 \\
\hline Union pour la Démocratie Française (UDF) & 131 & 22.7 \\
\hline Rassemblement pour la Republique (RPR) & 155 & 26.9 \\
\hline Front National (FN) & 35 & 6.1 \\
\hline non-associated deputies & 9 & 1.6 \\
\hline
\end{tabular}

Fig. 1. Political composition of the 8th Assemblée Nationale 1986-1988

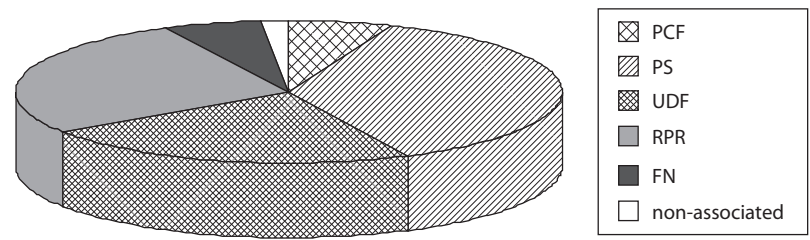

With the lost parliamentary elections, the President lost influence on the government. However, he was the undisputable leader of the Parti socialiste, which had a result good enough to make an important opposition. Due to these factors Mitter- 
rand's position, although weaker than before, was not completely reduced. Soon after the elections Mitterand remarked in an interview: "You do not choose a President for being idle." ${ }^{5} \mathrm{He}$ also indicated, that the President has broad prerogatives, even in relation to the government: "The President names [as Prime Minister] whom he wishes, although, of course, he has to respect the people's will [...] Nobody will choose the chief of government instead of me, trust me."6 However, he had a limited choice, compared to the situation, when he chose prime ministers from the PS. Jacques Chirac, the leader of the Gaullist Rassemblement pour la Republique (RPR) and the former Prime Minister in 1974-1976, was appointed chief of the government. The President did not have any influence on the construction of the government, either. Chirac chose for his ministers Gaullist politicians.

When the President represented a different political option than the parliamentary majority, his prerogatives were essentially revised. In 1985 Edouard Balladur even called the cohabitation "the moment of truth for the Fifth Republic's constitutional system." 7 The Constitution was read literally, making the head of state more of an arbitrator than an author - or co-author of the country's policies. A Polish historian, specializing in French history described Mitterrand's presidency during the $1^{\text {st }}$ cohabitation as follows: "[...] Mitterand protected the façade of presidential authority rather than the power itself. He made an impression of influencing instead of influencing indeed."

The Council of Ministers, presided by the President evidently lost its significance, which marked the President's diminished power. Although the constitutional obligation to hold the meetings of the Council of Ministers was strictly observed, the meetings of cabinet council (which consists only of the Prime Minister and his ministers) were held more often. This allowed the members of the government to discuss issues before presenting them to the President.

The President tried to influence internal policies by vetoing ordinances (ordonnances, i.e. acts of law issued by the government on parliamentary authorization). Mitterand used this instrument three times between 1986 and 1988, vetoing acts on re-privatization, on working time and setting new borders of constituencies. In the latter case, the head of state claimed that this matter did not lie in the government's competences, nevertheless, he criticized the acts' content. This was highly controversial, but did not lead to serious political consequences. At first, Chirac considered even shtml

${ }^{5}$ http://www.ladocumentationfrancaise.fr/dossier_actualite/cohabitation/campagne.

${ }^{6}$ Ibidem.

7 F.-O. Giesbert, Jacques Chirac, Paris 1987, p. 422.

8 J. Baszkiewicz, op.cit., p. 178. 
resigning of his post to protest against the President's actions, but finally Mitterand signed all these acts after they were passed by Assemblée Nationale as law (loi). ${ }^{9}$

As far as the economy is concerned, the Chirac government withdrew from the actions undertaken by the socialists (especially before 1983). Above all the Gaullist de-nationalized enterprises, selling banks and other companies, which had been nationalized by the socialist government of Pierre Mauroy (1981-1984) and restricted social law, accepted by the Assemblée Nationale between 1981 and 1986, while it was dominated by the Levy. The rightist government waived also price control and froze public administration salaries..$^{10}$ On the contrary, the President took clearly a leftist stand, he criticized the government for lack of protection of the poorest. In his opinion this could be dangerous to the society's cohesion. In propagating his views, Mitterand referred to the president's constitutional duty to protect the basic political principles. As the Preamble makes The Declaration of the Rights of Man and Citizen part of the current Constitution, the President is obliged to protect these rights as well. Mitterand used this fact as a pretext to criticize the government's social and economic policies. ${ }^{11}$ Of course, this had no legal effects, only political meaning. While the government determined and ran policy, the actions of the President were only symbolic, as he had no actual influence on the government's activities.

The relations between the President and the Prime Minister were different in the sphere of external policy. It traditionally belongs to the presidential domaine reservée. At the beginning of the cohabitation, the Prime Minister tried to present independent ideas in this sphere, including concepts of development and modernization of the French nuclear arsenal, opposing the President's positions. However, such proposals were presented only at the government's committees and not at the Council of Ministers. Thus, their realization was never seriously considered.

The President's dominance in international policy resulted not only from his constitutional and traditional prerogatives. Mitterand had also a broad experience in this sphere, while Chirac, trying to act internationally against the President, made mistakes, changed his mind, broke promises. He didn't know international politics, which became apparent in his inconsequent anti-terrorist policy (after a series of bomb attacks in Paris in September 1986). ${ }^{12}$ François Mitterand, whose line in foreign

9 R. Elgie, La cohabitation de longue durée: studying the 1997-2002 experience, "Modern \& Contemporary France", Vol. 10, No. 3, 2002, p. 303.

10 P. Bezes, Defensive versus offensive approaches to administrative reform in France (1988-97): the leadership dilemmas of French prime ministers, "Governance: An International Journal of Policy and Administration", Vol. 14, No. 1, January 2001, p. 12.

11 E. Popławska, Instytucja prezydenta w systemie politycznym V Republiki Francuskiej, Warszawa 1995, pp. 246-248.

12 F.-O. Giesbert, Jacques Chirac, op.cit., pp. 477-483 
affairs was both clear and known, controlled this sphere of French policy to a great extent.

Nevertheless, this situation did not give to rise tensions between two of the most important politicians in the country. Above all, Chirac could accept Mitterrand's policy, as it referred the Gaullist ideas, which the Prime Minister supported. Mitterand endeavoured to strengthen France's position as a global power, accentuated independence from the United States and stressed the meaning of national sovereignty in the process of European integration. ${ }^{13}$ Chirac remarked even that: "the cohabitation has shown, [...] practically there is general consent concerning foreign affairs and national defence." 14

There was another reason, why Chirac accepted the President's primacy in foreign affairs. He himself wanted to become the head of state (which he eventually achieved in 1995) and therefore he did not intend to restrict the President's political position, especially within the domaine reservée.

Of course, the relations between the President and the Prime Minister had to be settled and a borderline had to be drawn between prerogatives of the two elements of French executive. However, the atmosphere of the cohabitation was also influenced by the approaching presidential elections, especially as both opponents wanted to run for the post. On the one hand, Chirac's ambition led him to respect the prerogatives of the head of state and Mitterand did his best not to allow the conflict with Chirac to threaten his presidential image of a leader striving for national unity. ${ }^{15} \mathrm{On}$ the other hand, however, pre-election preparations and electoral campaign encouraged them to reveal variances and to reject the adversary's views. This is why the first cohabitation was named conflictuelle, hiperconflictuelle or even la campagne électorale prolongée (an extended electoral campaign).

\section{SECOND COHABITATION 1993-1995 \\ (MITTERAND-BALLADUR PERIOD)}

Political situation upon the beginning of second cohabitation was entirely different than in 1986. During the 5 years, when the PS governed during Mitterrand's second term (1988-1993) - the Levy compromised itself, both by the inefficient

13 A. Cole, Studying Political Leadership: the case of François Mitterand, "Political Studies", (1994), XLII, p. 465.

14 F.-O. Giesbert, Jacques Chirac, op.cit., p. 478.

15 W. Northcutt, François Mitterand and the Political Use of Symbols: The Construction of a Centrist Republic, "French Historical Studies", Vol. 17, No.1, Spring 1991. 
policies (at the beginning of the 1990s French economy was plagued with recession and unemployment, while the budget deficit increased) and by various scandals, financial above all. ${ }^{16}$ As a consequence the leftist parties - the PS and its former coalition partner Parti Communiste Français were spectacularly defeated, with the weakest result in the history of the Fifth Republic, while the rightist camp took more than $80 \%$ of seats in the newly-elected Assemblée Nationale (the RPR was represented by 257 deputies and the UDF had 215 MPs) ${ }^{17}$ (Tab. 2 and Fig. 2). The elections of 1993 removed Mitterrand's last remaining source of political legitimacy and virtually reduced the President to an observer status. ${ }^{18}$

Tab. 2. Second cohabitation, Mitterand-Balladur period, 1993-1995, composition of the 9th Assemblée Nationale:

\begin{tabular}{|l|c|c|}
\hline \multicolumn{1}{|c|}{ Party } & $\begin{array}{c}\text { number } \\
\text { of deputies }\end{array}$ & $\begin{array}{c}\text { percent } \\
\text { of deputies }\end{array}$ \\
\hline Parti Communiste Française (PCF) & 23 & 4.0 \\
\hline Parti Socialiste (PS) & 57 & 9.9 \\
\hline Union pour la Démocratie Française (UDF) & 215 & 37.3 \\
\hline Rassemblement pour la Republique (RPR) & 257 & 44.5 \\
\hline République et Liberté (RL) & 23 & 4.0 \\
\hline non-associated deputies & 2 & 0.3 \\
\hline
\end{tabular}

Fig. 2. Political composition of the 9th Assemblée Nationale 1993-1995

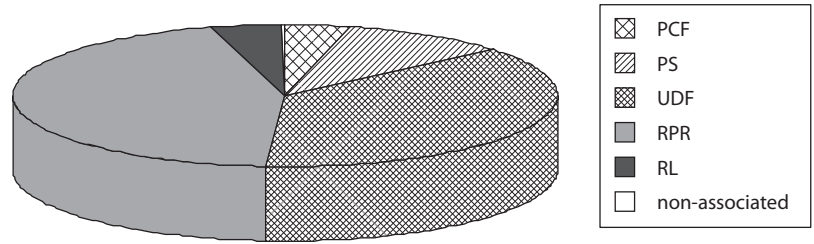

The political position of the head of state was weakened by other factors as well. Above all, he was not so strongly supported by the PS as he was during his first presidential term. His meaning in the party lessened. In the beginning of the 1980s, just like in the 1970s, Mitterand was an undisputable leader of the socialists. However,

\footnotetext{
16 J. Baszkiewicz, Historia..., op.cit., p. 604.

17 http://www.ladocumentationfrancaise.fr/dossier_actualite/cohabitation/velours. shtml

18 A. Cole, op.cit., p. 467.
} 
after 1988 the relations between the President and his political camp loosened. Soon after Mitterrand's re-election, Pierre Mauroy became the party's first secretary, against Mitterand, who wanted this post for Laurent Fabius. The President lost the ability to influence his own party, which made his situation even harder, as he faced the Prime Minister of the Right. ${ }^{19}$

The government was headed by Edouard Balladur, an experienced politician, who had been the Secretary-General of the President's Office during the presidency of Georges Pompidou (1969-1974) and minister of economy, finance and privatization in the government Chirac II (1986-1988). However, he was not a leader of the party, as the RPR was led until 1994 by Jacques Chirac. Nonetheless the party nominated Balladur as Prime Minister for two reasons. Firstly, Chirac's difficult experience of harsh cooperation during the first cohabitation made him a weaker candidate. Secondly, Chirac intended to run for president in the approaching presidential elections and he feared that managing current governance issues could affect his popularity and make his victory in the 1995 elections less likely. ${ }^{20}$

As a result of political weakness of the President of the Republic and of his party, the French politics during the second cohabitation was dominated by the Prime Minister and his government - even more so than in 1986-1988 period.

During the Mitterand-Balladur period moderation and conciliation prevailed over conflicts between the President and the Prime Minister, who proposed different political concepts. Their relations were also influenced by lack of personal political rivalry: the seriously sick Mitterand had no intention to fight for another re-election after the end of his second term; while Balladur, who was not a leader of his party - the RPR, did not initially plan to run for president in 1995 either (when he eventually changed this decision, the fact altered rather his relations with his own party than those with the head of state). Also, the Prime Minister's character encouraged easier cooperation with the President: contrary to the ambitious and impetuous Chirac, Balladur was calm and prone to search for compromises. ${ }^{21}$ All these issues were decisive for the atmosphere of the second cohabitation, which gained it such names as consensuelle, hiperconsensulle or even la cohabitation en velours (velvet cohabitation).

During the second cohabitation Mitterand resolved to accept the government's initiative in several areas. One of them concerned appointing the highest-level clerks, contrary to the 1986-1988 period, when the head of state had significant influence

19 F.-O. Giesbert, Le président, Paris 1990.

20 J.G. Shields, France's Presidential Elections: the Gaullist Restoration, "Political Quarterly", Oct-Dec 1995, Vol. 66, Issue 4.

${ }^{21}$ J. Baszkiewicz, Historia..., op.cit., p. 605; F.-O. Giesbert, Jacques Chirac, op.cit., p. 447-450 . 
on such decisions within the domaine reservée. Between 1993 and 1995 the Prime Minister only conferred about his decisions with the President. This resulted from Mitterrand's awareness that a government supported by more then $80 \%$ of the deputies has a very strong authorization to conduct policies of its own choice.

Nevertheless Mitterand remained an active politician. During the second cohabitation he used his constitutional prerogatives to the full, even against the parliamentary majority's will. In 1993 he refused to enter a debate on act on state schools funding to the agenda of an extraordinary session of Assemblée Nationale. ${ }^{22}$ He only managed to delay realization of plans of the rightist parties, but still he proved, that even a politically weakened President of the Republic is an important actor on the French political arena.

Prime Minister Balladur declared that the main goal of his government would be to fight economic recession. Although the rightist politician chose liberal strategy, the socialist president didn't endeavour to stop him from realizing it - although, of course, he had the right to veto proposed legal acts. His objection - to privatization, above all - was expressed at the meetings of Council of Ministers. ${ }^{23}$ The Balladur government froze public sector employees' salaries and had labour costs decreased, against the opinion of leftist trade unions. ${ }^{24}$ The ministers took also actions to reform the pension system - first of all the government restricted raises of pensions, linking them to inflation instead of salaries. ${ }^{25}$

Just like during the first cohabitation, the government's economic and social policies were absolutely free from the President's influence. Mitterand never tried to use his presidential abilities to contain these policies, although he often opposed them.

In March, 1993, soon after the electoral defeat of the PS, Mitterand assured, that he would "observe meticulously the will announced by the electorate", but he mentioned also, that he would "guard the continuity of foreign policy and defence". ${ }^{6}$ Just like during the first cohabitation, the double representation principle was accepted by the President and the Prime Minister: both Mitterand and Balladur participated in the most significant international conferences, but this fact did not bring about any problems concerning the unity of French foreign policy. There were only small

22 http://www.ladocumentationfrancaise.fr/dossier_actualite/cohabitation/velours. shtml

23 R. Elgie, op.cit., p. 303.

24 J. Valls-Russel, Balladur riding the waves, "New Leader", Vol. 76, Issue 11-9.06.1993.

25 B. Palier, Réformer les retraites en France, "French Politics, Culture \& Society", Vol. 21, No. 3, Fall 2003, pp. 58-59.

${ }^{26}$ http://www.ladocumentationfrancaise.fr/dossier_actualite/cohabitation/balla.shtml 
discrepancies of opinions between the two politicians and they avoided arguments, which could weaken international position of the French Republic.

The most serious conflict of all Mitterand-Balladur period concerned nuclear testing and modernization of French nuclear arsenal. Such concepts had been risen by the Gaullist since the 1980s and Prime Minister Balladur endeavoured to put them into practice, while the President was strongly opposed and pointed out to the nuclear testing moratorium, which was in force. Mitterrand's stand prevailed, as - according to the tradition and to a decree of 1964 - it is the head of state, who is in charge of nuclear weapons in the Fifth Republic. According to art. 20 of the Constitution, the government "has at its disposal [...] the armed forces", but nevertheless the Gaullists recognized, that the most important decisions in the domain of defence should be taken by the President. ${ }^{27}$

His weak political position and serious illness made President Mitterand an easier partner for the Prime Minister during the second cohabitation than he had been in the Mitterand-Chirac period. The actual political conflict was not between the socialist President and the rightist Prime Minister, but between Balladur, who had an increasing support in the society, and Chirac, the leader of the RPR and its presidential candidate. Relations between the two Gaullist politicians turned even harder, when it turned out, they would face each other in the 1995 elections. Chirac often criticized policies of the government, thus accentuating his social sensitivity, as opposed to Balladur's liberal approach to economy. This made it more difficult for the Prime Minister to cooperate with the Assemblée Nationale, as the RPR was the strongest party of the rightist coalition. At the same time, Balladur's decision to run for president, rendered collaboration between the coalition partners harder as well: Tthe centrist Union pour la démocratie française supported the Prime Minister, and not Chirac. Eventually the Mitterand-Balladur period became "a cohabitation, hiding another cohabitation - within the rightist coalition".28

\section{THIRD COHABITATION 1997-2002 \\ (CHIRAC-JOSPIN PERIOD)}

In 1997, for the first time in history of the Fifth Republic, cohabitation started with early elections, organized after the President dissolved the Assemblée Nationale one year before the end of its constitutional term. The Gaullist President, Jacques

27 E. Popławska, op.cit., pp. 250-251.

28 http://www.ladocumentationfrancaise.fr/dossier_actualite/cohabitation/velours. shtml 
Chirac decided to dissolve the Parliament, while the strongest parliamentary fraction was his own party, the RPR, holding an overwhelming majority together with its ally, the UDF. He made this decision because of wide-spread protests against reforms introduced by the rightist government and soaring support for the RPR and UDF, shown by poll surveys. He was convinced, that in potential elections in the constitutionally fixed date, in 1998, his political allies would face defeat, Chirac hoped to avoid cohabitation with early elections. This decision, however, was against political traditions of the Fifth Republic: for previous presidents dissolving of the Assemblée Nationale was an ultimate instrument, used only in very special circumstances and never a matter of political calculations. Two of them - Georges Pompidou and Valéry Giscard d'Estaing had never dissolved the parliament. De Gaulle had done it twice, once in 1962, when the deputies had passed a vote of no confidence for the government of Pompidou, supported by the President, and for the second time in 1968, after the May crisis. Mitterand had ruled early elections in 1981 and in 1988 after he had been chosen president, while the Right had been dominating in the Assemblée Nationale. Chirac's motivation was utterly different, which made his decision highly controversial.

In those elections the rightist camp lost half of its seats in the Parliament. The strongest fraction was the Parti Socialiste, but it did not win an absolute majority.29 This is why the socialists decide to enter a coalition with other leftist parties: Parti Communist Français, environmentalists and radicals ${ }^{30}$ (Fig. 3 and Tab. 3).

Tab. 3. Third cohabitation, Chirac-Jospin period, 1997-2002, composition of the 10th Assemblée Nationale:

\begin{tabular}{|l|c|c|}
\hline \multicolumn{1}{|c|}{ party } & $\begin{array}{c}\text { number } \\
\text { of deputies }\end{array}$ & $\begin{array}{c}\text { percent } \\
\text { of deputies }\end{array}$ \\
\hline Parti Communiste Française (PCF) & 36 & 6.2 \\
\hline Parti Socialiste (PS) & 250 & 43.3 \\
\hline Radical, Citoyen et Vert (RCV) & 33 & 5.7 \\
\hline Union pour la Démocratie Française (UDF) & 113 & 19.6 \\
\hline Rassemblement pour la Republique (RPR) & 140 & 24.3 \\
\hline non-associated deputies & 5 & 0.9 \\
\hline
\end{tabular}

${ }^{29} \mathrm{http}: / /$ francepolitique.free.fr/AN5.htm\#111

${ }^{30} \mathrm{http}$ //francepolitique.free.fr/gouvjospin.htm; E. Gdulewicz, System konstytucyjny Francji, Warszawa 2000, p. 89. 
Fig. 3. Political composition of the 10th Assemblée Nationale 1997-2002
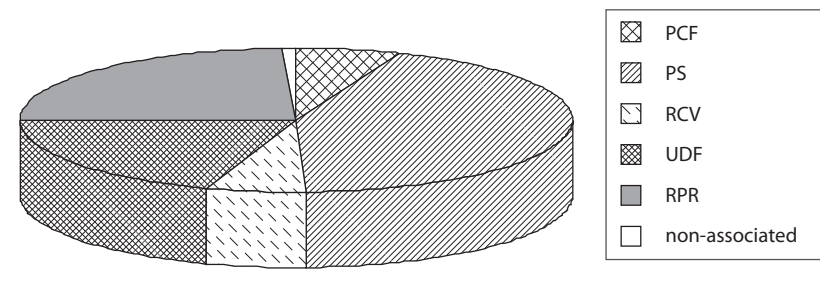

Their government was headed by Lionel Jospin, the first secretary of the PS (he occupied this post between 1981 and 1988 and then between 1995 and 1997) and the former minister of education. His position in his party was strong, but this didn't actually mean strong political support. Both the Prime Minister and his government were weakened, because the coalition - called la gauche plurielle was not consistent. Especially the communists were often opposed to the government's stand, even though politicians of the PCF took ministerial portfolios. ${ }^{31}$

As the Assemblée Nationale was chosen in early elections, according to art. 12 of the French Constitution, the President had no right to dissolve it for one year. Even after this term, Chirac decided not to rule new elections and the parliament served its entire, five-year-long constitutional term. For the first time cohabitation lasted longer than two years. This could mean, that practices typical for this period, would make an integral part of French political life for longer. ${ }^{32}$

Like on the previous occasions, both the President and the Prime Minister declared, that the main principle of their cooperation would be observance of constitutional prerogatives of particular authorities. However, division of competencies in the executive of the Fifth Republic was still positively unclear and subsequent cohabitation periods had not made it any more distinct: "lines of decision-making and responsibility had often seemed blurred".33 Although the President's political position had been significantly weakened, Chirac indicated in a TV interview, that "The Constitution [...] gives a certain superiority and [...] to some extent it leaves the last word with the President of the Republic". The newly-appointed Prime Min-

31 P. Buffotot, D. Hanley, Léclatement de l’offre politique: les élections européennes de juin 1999, "Modern \& Contemporary France" 2000, 8(2), p. 158.

32 http://www.ladocumentationfrancaise.fr/dossier_actualite/cohabitation/courte. shtml

33 P. Buffotot, D. Hanley, The normalisation of French politics? The elections of 2002, "Modern \& Contemporary France" 2003, Vol. 11, No. 2, p. 131. 
ister Jospin reacted two days later, stressing, that "There is no domain in the French politics, in which the last word would belong to the President". ${ }^{34}$

Nevertheless, the perspective of a "long-standing" cohabitation encouraged both politicians to soothe the potential conflict. At the beginning of the parliament's term, President Chirac declared: "naturally, this one will be a cohabitation constructive". ${ }^{35}$ However, conflicts between the head of state and the chief of government rose, especially that both of them seemed quite natural 2002 presidential candidates of their political camps: Chirac as the leader of the RPR, the biggest party on the right; and Jospin as the front man of the PS, who dominated the left. At the end of this cohabitation, Chirac described it as "quasiment dévastatrice". ${ }^{6}$

A political scientist, Robert Elgie, divided the five-year-long Chirac-Jospin cohabitation into three stages. In the first one, until 1998, Chirac didn't oppose the government explicitly, respecting, that the gauche plurielle had a strong electoral authorization to govern. He focused on criticizing splits in his own political camp and tried to restore his personal position in the party, deprived of parliamentary majority, due to his decision to dissolve the Assemblée Nationale. In the next stage, dated by Elgie 1998 to 2001, the President of the Republic commenced to assess the government actions, criticizing the Levy as inefficient and passive in such domains as the pension system and internal security. Eventually, in the final stage of ChiracJospin cohabitation, the nature of collaboration between the two of the most important politicians in France mimicked the characteristics of Mitterand-Chirac period. The conflict between the President and the Prime Minister intensified because of the approaching elections, in which both politicians, occupying the major executive posts of the Fifth Republic, intended to run for president. ${ }^{37}$ The final period of the "institutional coexistence" of the leftist government and the Gaullist President was even referred to by a formalist of the daily "L'Express" as "Chronicle of hatred". ${ }^{38}$

Nevertheless, discrepancies of political opinions between Jospin and Chirac could not withhold the government from realizing its concepts. The President was not able to prevent shortening of the working week to 35 hours, designed as a means of reducing unemployment rate. He did call it a "hazardous experiment" ${ }^{39}$ and the rightist camp opposed it strongly. There was also a conflict concerning broadening of autonomy of province of Corsica, but, here, as well, the President could not influence the government's policy. Everything he could do was to express his protest in

\footnotetext{
${ }^{34}$ http://www.ladocumentationfrancaise.fr/dossier_actualite/cohabitation/chirac.shtml 35 Ibidem.

36 R. Elgie, op.cit., p. 309.

37 Ibidem, pp. 307-309.

38 R. Rosso, E. Mandonnet, C. Barbier, Chronique de la haine, "l'Express", 25.10.2001.

39 P. Buffotot, D. Hanley, The normalization..., op.cit., p. 137.
} 
a symbolic way: he refused to enter the issue to the Council of Ministers' agenda. The sole result of this move was to delay the debate on this reform by a week. ${ }^{40}$

Also the field for the President's own initiatives was not broad. Their success depended strictly on the government's support, which can be clearly exemplified by the pension system's reform. Chirac found it necessary, but the leftist government not only failed to take any actions to amend the system, but it even adjourned realization of solutions, accepted by the previous government, headed by Alain Juppé. The President of the Republic criticized the government for passivity toward this issue, but the Prime Minister resolved only to organize debates and prepare analysis to elaborate guidelines of a future reform. ${ }^{41}$

Internal policies, just like in the Mitterand-Chirac and Mitterand-Balladur periods belonged therefore to the government, while foreign policies stayed under the distinct presidential influence. It resulted on the one hand from the Fifth Republic tradition (not only Gaullist one) of the domaine reservée and from the constitutional provisions, stipulating, that it is the President, who negotiates international treaties; and on the other hand - from Jospin's inexperience in this domain, which mimicked the situation of the first cohabitation. In February 2000, the Prime Minister made a comprising blunder during his official visit in the Middle East: he called Hezbollah a terrorist organization. In effect a group of outraged Arabs threw stones at him. ${ }^{42}$ The President declared that "wished to see him on his return", thus reproaching the Prime Minister publicly and reminding him, that foreign policies belong to the head of state's domaine reservée. ${ }^{43}$

The President preserved also some influence on law-making, because the right had still a majority of seats in the Senate. This is why the RPR and its allies managed to block some reforms in the second chamber: the most important, they prevented prohibition of combining parliamentary and government positions with local authorities' posts by single politicians. ${ }^{44}$ However this was only another way to hamper la gauche plurielle from implementing its idea, and not a method of introducing solutions preferred by the pro-presidential parties. Lionel Jospin skilfully used such instruments as joint committees, mediating between the two chambers, which allowed him to reduce practical meaning of the Senate.

40 R. Elgie, op.cit., p. 303.

41 B. Palier, op.cit., pp. 58-61.

42 R. Elgie, op.cit. p. 307.

43 J. Gaffney, Protocol, image, and discourse in political leadership competition: the case of prime minister Lionel Jospin, 1997-2002, "Modern \& Contemporary France" 2002, Vol. 10, No. 3, p. 319.

44 R. Elgie, op.cit., p. 307. 
Lionel Jospin's term as prime minister was the second longest in the history of the Fifth Republic (the longest one was Georges Pompidou's, who served at this post for 6 years, 1962-1968, while Jospin - for 5 years) and his government's activities were basically regarded as successful. ${ }^{45}$ However, the Prime Minister's popularity fell, while more and more citizens assessed Chirac's presidency high ${ }^{46}$ In the elections in 2002, at the end of the third cohabitation, la gauche plurielle was overwhelmingly defeated and the presidential Union pour la majorité presidentielle won an absolute majority of seats in the Assemblée Nationale.

\section{CHARACTERISTIC FEATURES OF ALL THE THREE COHABITATIONS}

As Elgie pointed, there are two possible approaches to cohabitation and to all other phenomena analysed by political science as well. The first one treats each cohabitation as a separate problem, indicating a unique political configuration, in which president and prime minister are forced to coexist. This idea, chosen by Hugues Portelli, focuses on an analysis of special features of particular cohabitations and of factors, which shaped the institutional coexistence. The other approach, represented by Jean-Luc Parodi and Olivier Duhamel, concentrates on finding regularities, observed in all the three cohabitations, despite differences among them. ${ }^{47}$

In all three described periods the government's position was significantly strengthened - both in regard to the head of state and in relation to the legislative. The president lost influence not only on ministerial nominations, but on the government's program as well. Both François Mitterand and Jacques Chirac respected the will of citizens, who had supported propositions offered by the opposition and not the presidential camp. Therefore neither of them endeavoured to change the government's priorities. The president's role in shaping policies lessened, while there were more meetings of ministers without him (called conseil de cabinet or réunion des ministres). Meetings of the complete council of ministers (i.e. including the presidents) were less of a policy-making body and more of a forum for the president, on which he could pronounce his disapproval of the government's policies. ${ }^{48}$

As far as foreign policy is concerned, a will to find a compromise was clearly visible in all the three periods. The "cohabitants" invariably stressed the necessary

45 A. Miguet, The French Elections of 2002: After the Earthquake, the Deluge, "West European Politics" 2002, Vol. 25, No. 4, s. 209.

46 J. Gaffney, op.cit., p. 320.

47 R. Elgie, op.cit., pp. 297-301.

48 E. Gdulewicz, op.cit., p. 60. 
cohesion and clarity of France's international activities. Traditionally, this field is recognized in the Fifth Republic as the presidential domaine reservée and during cohabitation, just like in all other periods, the head of state was much more active in the area of external policy than of internal ones.

An important feature, characteristic for all the three periods of cohabitation in the history of the Fifth Republic, is a trend to reduce political role of the parliament. There are different instruments, which can be used for this purpose: a proposed legal act can be categorized as urgent, resulting in shortening of the debate on it in the Assemblée Nationale; combining the vote on an act with a vote on confidence for the government, according to art. 49 of the Constitution: in consequence there is no discussion in the Parliament, if no-one submits a motion of no confidence); finally, appointing a joint committee, if there is co concordance between two chambers (if the committee doesn't reach an agreement, the act can be passed by the Assemblée Nationale, regardless of the Senate's opinion). ${ }^{49}$

However, such proceedings were more frequent during the Mitterand-Chirac periods (when the government's predominance in the Assemblée Nationale was not big) and during the Chirac-Jospin period (when the Senate opposed the government) than in the Mitterand-Balladur period (when the government was supported by a vast parliamentary majority). This could suggest, that lesser role of the Parliament resulted from particular political circumstances rather than from the nature of cohabitation itself.

Another thing, important for a political scientist, is strengthening of political parties during cohabitation. They can gain a more significant influence on the government, which depends then solely on support offered by parliamentary fractions. Unlike the situation, when the dual executive is politically uniform, during cohabitation, the prime minister cannot lean on the president.

However, despite the bigger influence on current policies, gained by the government forced to cooperate with an oppositional president, this situation does not serve popularity of governing parties and prime minister himself. In 1986, in 1993 and in 1997 as well, citizens' approval rate of prime minister of the victorious party and of the president of the defeated opposition, were comparable. But during the cohabitation, prime minister's popularity either fell faster than the head of state's approval or rose more slowly. ${ }^{50}$ Parties, which had supported the "cohabitation governments" were all defeated in subsequent parliamentary elections: in 1988, 1995 and 2002.

All the cohabitant prime ministers ran for president in elections after cohabitation and all three lost. Only Chirac in 1995 managed to enter the second round, while

49 Ibidem, pp. 302-303.

50 J. Gaffney, op.cit., p. 320. 
both Balladur in 1995 and Jospin in 2002 rated third. Twice the cohabitant presidents were candidates in such elections (Mitterand in 1988 and Chirac in 2002) and they were both re-elected. In 1995, when the president did not take part in the elections, out of the politicians, who entered the second round, none had any post in Balladur's cabinet (1993-1995) and the first round was won by Lionel Jospin, who represented the same party as the outgoing president François Mitterand.

Concluding, one can say, that during cohabitation, it is the prime minister, who is actually in charge of the country's policies, while the president becomes "relatively politically irrelevant". ${ }^{11}$ However, such a division of political influence actually made it easier for the presidents to built a statesman-like image of a head of state guarding the nation's cohesion and the state's continuity. As a result cohabitation is actually an advantage both for the president and the parties, who support him, when it comes to post-cohabitation elections (so far all periods of cohabitation ended in a year of presidential elections and two of them - in 1988 and 2002 - parliamentary elections as well).

\section{CONCLUSIONS}

Cohabitation is possible in any political system, where main actors of a dual executive are chosen in separate elections. However, only in the semi-presidential systems this phenomenon has a unique meaning. As both the head of state and the chief of government have distinct prerogatives of conducting policies, their political unity or political discrepancies between them force a particular shape of relations between the major state organs.

Constitutional division of prerogatives of organs of executive power in the Fifth Republic is unclear and then the system was significantly "presidentialized" in 1958-1986. Before cohabitation actually happened, these factors caused serious fears concerning durability of the system or even French democracy itself in case of lack of unity within the executive. However, three periods of cohabitation, which lasted 9 years in total, proved rather the system's stability and not its weakness, showing, that the institutions of the Fifth Republic are able to adapt to various political circumstances.

From the creation of the Fifth Republic in 1958 until 1981 all the presidents represented the right - either Gaullist or liberal. At the same time the Assemblée Nationale was dominated by the pro-presidential parties. During the next five years - from the alternance till 1986 both the president and the government represented

51 Ibidem, p. 321. 
the levy. During the whole period of the executive's political unity - regardless of the fact which bloc held the power - the head of state's prerogatives were interpreted broadly and the other of the main executive organs was subordinate to the president. These tendencies concerned both decisions on appointment of clerks and on directions of policies. This is when the concept of domaine reservée was elaborated. According to these idea, foreign policy and defence were recognized as presidential prerogatives, regardless of constitutional provisions regulating these issues.

This construction, adopted by Charles de Gaulle and his successors was often quite far from literal interpretation of the 1958 Constitution. It was possible, because the elementary act of law is quite unclear. The President's role is described with such terms as "arbitration", "guarantor", without precise stipulation, how these tasks should be accomplished. Division of competencies between the President of the Republic, the prime minister and the government is not necessarily unequivocal. There are areas, where both main organs have significant prerogatives.

This is why, while the executive is politically united, the actual partition of power depends specifically on personalities of the president and his prime minister. The prime-ministerial term of Pierre Messmer (1972-1974) during the presidency of Georges Pompidou was often referred to as the time of "presidentialization of the political system”; whereas Prime Minister Michel Rocard (1988-1991) during the presidency of François Mitterand conducted independent policies apart from realizing the head of state's program. But the situation was completely different during cohabitation, when the chief of government represented the President's opposition and endeavoured to strengthen his own power by restricting presidential influence.

There were some features characteristic for all three periods of cohabitation: main decision-making competencies were taken over by the government and the president's position was weakened. At the same time, even if the main political actors were in conflict, some compromises and cooperation were necessary. These means, typically consensual, were especially remarkable in the domain of foreign affairs, but they encouraged also the development of consensus in other areas, thus softening competition between political parties.

The political system worked differently during cohabitation, but it did not modify political practice permanently. Three times after cohabitation, single option captured presidency and government: the socialists Mitterand and Rocard in 1988, the Gaullists Jacques Chirac and Alain Juppé in 1995 and finally Chirac and JeanPierre Raffarin in 2002. Although the relations between the main executive organs varied, none of these three prime-ministers acquired an independence compared to that enjoyed by Chirac, Edouard Balladur and Lionel Jospin as cohabitant prime ministers. After the first cohabitation, the politician appointed prime minister was Michel Rocard, who had not been a close collaborator of the President, he had even 
competed with Mitterand for the leadership of the Parti Socialiste for many years. ${ }^{52}$ As a result he had quite broad opportunities to manage the state. This could indicate, that cohabitation had actually reshaped permanently the relations between the two most important politician in France, enforcing position of the government and its chief against the head of state. However the next years brought prime-ministerial terms of Edith Cresson (1991-1992) and Pierre Bérégovoy (1992-1993) and then Juppé (after the second cohabitation: 1995-1997) and Jean-Pierre Raffarin (after the third cohabitation: 2002-2005). While those politicians, who represented the same parties as the president in office, were in power, the French policies were dominated by the head of state. Rocard's decision-making freedom resulted, as I mentioned above, from the personal relations between him and Mitterand rather than from the experience of the first cohabitation.

Cohabitation appears to be treated as an exceptional situation, interception of political unity of the president and the parliament, recognized as the appropriate political configuration for the semi-presidential system. Prime Minister Lionel Jospin said to the Assemblée Nationale in 2000: "Cohabitation is always possible, if the French cause it by their vote. But it has to be thought of as brackets. And in politics, just like in literature, brackets should be brief". ${ }^{53}$ A similar opinion was expressed by a Polish political scientist, Wiesław Skrzydło: "[cohabitation] cannot be of permanent nature, it's a temporary state, which does not destroy the political system's foundations and poses no threat to its existence." ${ }^{54}$

However, the cohabitation did actually influence the functioning of the French political system by forcing particular institutional changes. Whereas the first 30 years of the Fifth Republic were the time of political unity of the president and prime minister, during the next 20 years, the cohabitation lasted almost half of this time. Cohabitation was no more an exception and it did not arise huge emotions any more. At the beginning of the third cohabitation, there were no significant appeals for the president's resignation after his party's defeat and such opinion were expressed in 1986 and 1993 by such an important politician as the former Prime Minister Raymond Barre. After 1978 on no occasion did the presidential party win elections during the head of state's term in office.

The first two periods of cohabitation were times of conflicts and malevolence between the country's crucial politicians. During the third cohabitation such

52 F.-O. Giesbert, Le président, op.cit., Paris 1990, pp. 390-405.

53 http://www.ladocumentationfrancaise.fr/dossier_actualite/cohabitation/jospin.shtml

54 W. Skrzydło, Ustrój polityczny Republiki Francuskiej, [in:] Ustroje państw współczesnych, E. Gdulewicz, W. Kręcisz, W. Ormowski, W. Skrzydło, W. Zakrzewski (eds.), Lublin 2000, p. 156. 
unfriendliness led even to serious decision-making difficulties..$^{55}$ As a consequence, cohabitation was seen as "an unstable, paralyzing arrangement". ${ }^{66}$ In these circumstances special measures were taken in order to lessen the risk of reoccurrence of coexistence of opposing president and parliamentary majority. The first one was the shortening of presidential term, making it equal to the term of the Assemblée Nationale; and the other one was delaying the parliamentary elections in 2002 so that it would be held after the presidential elections. Reversing the [elections'] calendar turned it upside down" and retrieving "the logical sequence of elections", as Prime Minister Lionel Jospin put it ${ }^{57}$, would make the newly elected head of state's name known before parliamentary elections, encouraging election of a pro-presidential Assemblée Nationale.

An amendment of the constitution, changing the President's term from 7 to 5 years, decreases the probability of reoccurrence of cohabitation. The next elections after this revision took place in a single year: 2002 and as now the terms are equal the two electoral cycles were thus linked. It was assumed, that majority of voters would support the same camp in two elections held in one year more pronably, than in the case of elections with several years' interval between them and this would make cohabitation a much less frequent phenomenon of French politics. Even if the president would die, resign or get impeached, the electoral cycles wouldn't necessarily be parted, because his successor could announce early parliamentary elections at the beginning of his term.

However, Thomas A. Sancton points out to a risk that president and parliamentary majority chosen in elections held month after month could represent opposing political camps too. He believes, that this could be dangerous for the system, because in that case, contrary to the mid-term elections, legitimacy of the president and parliament would be analogical and there would be no difference of "freshness of legitimacy". Of course, in such a case, the president would have the right to dissolve the Assemblée Nationale, but another defeat would mean a downfall of the head of state's position, which is contrary to the system's practices so far. ${ }^{58}$

Two elections were held until now after the amendment of the Constitution. In both cases the newly elected President of the Republic - Jacques Chirac in 2002 (Fig. 4 and Tab. 4) and Nicolas Sarkozy in 2007 (Fig. 5 and Tab. 5) - led his party to an overwhelming victory, taking more than $60 \%$ of seats in the Assemblée Nationale. Especially in 2007 the parliamentary elections were actually reduced to a referendum,

55 P. Buffotot, D. Hanley, The normalization..., op.cit., p. 132.

56 T.A. Sancton, Is it time for a Sixth Republic?, “Time”, 21.04.2003, Vol. 161, No. 16, www. time.com/time/europe/magazine/2002/0422/cover/viewpoint.html

57 http://www.ladocumentationfrancaise.fr/dossier_actualite/cohabitation/jospin.shtml

58 T.A. Sancton, op.cit. 
Tab. 4. Composition of the 11th Assemblée Nationale, 2002-2007:

\begin{tabular}{|l|c|c|}
\hline \multicolumn{1}{|c|}{ party } & $\begin{array}{c}\text { number } \\
\text { of deputies }\end{array}$ & $\begin{array}{c}\text { percent } \\
\text { of deputies }\end{array}$ \\
\hline Députées Communistes et Républicains (COM) & 21 & 3.6 \\
\hline Parti Socialiste (PS) & 141 & 24.4 \\
\hline Union pour la Démocratie Française (UDF) & 29 & 5.0 \\
\hline Union pour la Majorité Présidentielle (UMP) & 365 & 63.4 \\
\hline non-associated deputies & 21 & 3.6 \\
\hline
\end{tabular}

Fig. 4. Political composition of the 11th Assemblée Nationale 2002-2007
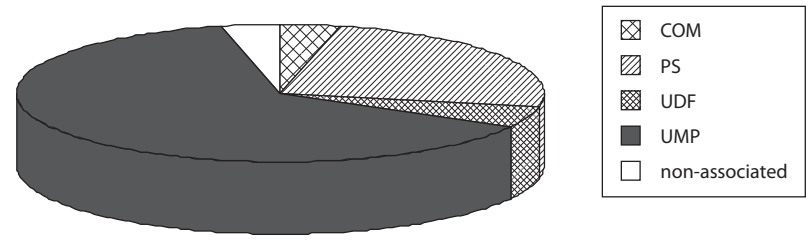

Tab. 5. Composition of the 12th Assemblée Nationale, post-2007:

\begin{tabular}{|l|c|c|}
\hline \multicolumn{1}{|c|}{ party } & $\begin{array}{c}\text { number } \\
\text { of deputies }\end{array}$ & $\begin{array}{c}\text { percent } \\
\text { of deputies }\end{array}$ \\
\hline Députées Communistes et Républicains (COM) & 21 & 3.7 \\
\hline Parti Socialiste (PS) & 149 & 26.0 \\
\hline Union pour la Démocratie Française (UDF) & 29 & 5.0 \\
\hline Union pour un Mouvement Populaire & 359 & 62.7 \\
\hline non-associated deputies & 14 & 2.4 \\
\hline
\end{tabular}

Fig. 5. Political composition of the 12th Assemblée Nationale, post-2007:

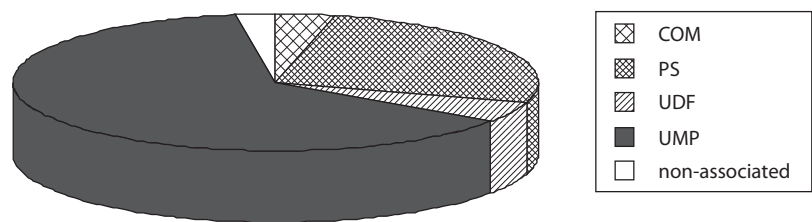


re-enforcing the President after his first victory and confirming his legitimacy to introduce serious reforms and bold policies.

Cohabitation modified also in a way the patterns of political competition between the parties. It strengthened the so-called "presidential effect", observed from the Fifth Republic's very beginning. The effect the encourages two-bloc party system, as two camps are shaped: a pro-presidential camp and its opposition. Compared to the times of political unity of the executive, cohabitation requires much stricter consolidation of the pro-presidential political fractions, as evidenced by the unification of the right in 1997-2002, leading ultimately to creation between the two rounds of the 2002 presidential elections of the Union pour la Majorité Présidentielle (renamed Union pour un Mouvement Populaire in November 2002). This was aimed to balance the pro-government camp, uniting all parliamentary leftist fraction around the government of Lionel Jospin.

At the same time, the two blocs become more consolidated, thus making the French party system more like a two-party system. At the levy we observe downfall of the communist and radical parties. The Parti Socialiste dominates this part of political stage. No leftist fractions other than the socialists, play any significant role in either presidential or parliamentary elections. Communists and greens are no more important players in the Assemblée Nationale, regarding their meagre coalition potential: neither of them could participate in any other coalition than with the PS, while the Socialists in 1998 had an alternative option of minority government, in case the Communists refused to co-operate with them. Whereas the process of concentration of the levy started in the early 1980s, it was more evident that cohabitation, together with the rise of the nationalist Front National and other factors, influenced similar activities at the right. Since the 1970s there had been two important rightist parties of comparable potential: the Gaullists and the liberals. This situation was changed in 2002, when the Gaullist RPR and breakaway groups of the liberal UDF created together the UMP, which took independently almost $2 / 3$ of the parliamentary seats (more than tenfold the liberals' representation). Thus, the UMP's current role at the right is similar to the PS's dominant position at the levy. It is remarkable, however, that this process was not only maintained but even enforced later, therefore after the described amendment of the Constitution, practically eliminating political parties other than the two dominant ones. The combined parliamentary representation of the UMP (dominant rightist force) and PS (dominant leftist force) made almost 90\% of the Assemblée Nationale elected in 2007and 87\% after the 2002 elections, whereas the analogical index for the Assembly elected in 1997 (including RPR and PS) equalled $66 \%$ and for the 1993 elections (including RPR and PS) - only $54 \%$. This could indicate, that these processes are characteristic for the system of the Fifth Republic itself and do not result from cohabitation. 
The co-existence of opposing head of state and chief of government, who represented different ideas and political concepts, influenced not only the institutional aspect of partisan competition. There were also remarkable modifications of political programs. Although the president's influence on the government's policies was reduced during the cohabitation, he still presided formally over the Council of Ministers and with his law-making prerogatives - including the rights to announce a referendum or early elections - he did have some instruments to pressure the prime minister and his government. This balances the system, forcing political actors to soothe their stances and avoid radical undertakings. This makes the politics increasingly consensual, as the American political scientist Nick Hewlett points out. ${ }^{59}$ At the same time political discrepancies between the main forces become dim: "A total of nine years of cohabitation no doubt blurred the distinctions between those in power. The similarities of projects of the two main candidates [in the 2002 presidential elections] - Chirac and Jospin - were obvious to all".60 This convergence concerns internal policies, as the wide acceptance of the Gaullist concepts of foreign policy has been typical of French politics since as long ago as the 1980s (Mitterrand's first term as the President).

Cohabitation proved flexibility of institutional solutions adopted in the Fifth Republic. With different political circumstances, the system's practice changed too. According to Prime Minister Jospin, today, "[the chief of the government] contributes to reviving the parliamentary aspect of [the Fifth Republic's] regime". ${ }^{61}$

Some researchers point out, that the semi-presidential system, being mixed and threatened with instability in case of political discrepancies within its executive, is especially vulnerable to develop into an authoritarian rule. ${ }^{62}$ However, various political constellations in the Fifth Republic's executive actually evidenced the democratic system's stability, regardless of the president and prime minister's relations. It would be rather justified to suggest that an anti-democratic risk would depend on whether the democracy is consolidated or not and other factors specific for a particular country than on the type of regime.

The French semi-presidential system doesn't appear to develop into any other type of democratic regime. Although during cohabitation its parliamentary aspects are more remarkable and while the executive is united - presidential ones, neither the former, nor the latter prevail permanently: after cohabitation, the head of state's posi-

59 R. Gildea, Charting contemporary French politics, "Modern \& Contemporary France" 1999, Vol. 7, No. 3.

60 A. Miguet, op.cit., p. 212.

61 http://www.ladocumentationfrancaise.fr/dossier_actualite/cohabitation/jospin.shtml

62 For instance: B. Banaszak, Prawo konstytucyjne, Warszawa 2004. 
tion is usually reinforced, when after elections the two executive organs once more represent one fraction. This confirms the theory that a semi-presidential one is not actually a combination of features of the other "ideal types". It can be interpreted as an alternative system, being closer to presidentialism while the executive is united and close to parliamentarian rule, if a president cohabits with an opposing prime minister. ${ }^{63}$ The "parliamentary", or cohabitation periods were characterized by a more literal construction of provisions of the Constitution, while the "presidential" times of united executive - a more distinct reference to the Gaullist tradition of a dominating presidency. However, none of the configurations required modifications in law. These were introduced only as late as in 2000: in the middle of the third cohabitation.

This amendment of Constitution may actually turn out to modify the presidentparliament relations. Reducing the risk of cohabitation seems to have strengthened the president even more.

${ }^{63}$ E. Popławska, op.cit., p. 220. 